E-ISSN : 2549-6581

DOI: 10.21776/ub.JOIM.2019.003.03.4

Artikel Hasil Penelitian

Diterima : 10 Juni 2019

Direview : 16 Oktober 2019

Dimuat : Desember 2019 - Maret 2020
OPEN ACCESS

Journal of Issues in Midwifer

\title{
Perbedaan Efektifitas Stimulasi Bahasa Metode Glenn Doman Melalui Flashcard Bergambar dan Flashcard Tulisan Terhadap Perkembangan Bahasa Anak Usia Prasekolah di Kelompok B TK Al-Jihad Kota Malang
}

\author{
Khansa Nisrina Firdaus $^{1 *}$, Lilik Indahwati ${ }^{2}$, Linda Ratna Wati ${ }^{2}$ \\ ${ }^{1 *}$ Program Studi S1 Kebidanan, Fakultas Kedokteran, Universitas Brawijaya, \\ Email: khansanfirdaus@gmail.com, Tlp : +6285649589436 \\ ${ }^{2}$ Program Studi S1 Kebidanan, Fakultas Kedokteran, Universitas Brawijaya, Email: \\ lulikw.ub@gmail.com; linda.ratna13@gmail.com
}

\begin{abstract}
Golden age is an optimal period of growth and development. Language development as one of the indicator of speaking skill and children's language development does eventually delayed in preschool period. It is necessary to give appropriate language stimulation to improve developmental by using flashcardas an intervention. The purpose of this study is to determine the difference in the effectiveness of Glenn Doman's language stimulation method using an illustrated flashcard and writing flashcard to the language development of preschool children in group B.This quasi experimental study was conducted using pretest-posttest one group design involving 32 children in February-March 2019. The development of language was measured by DDST II (Denver Development Screening II). Analysis using Mann Whitney test showed p-value $0.551>0.05$. It is concluded that there is no significant difference in the effectiveness of Glenn Doman's language stimulation method using an illustrated flashcard and writing flashcard to the language development of preschool children group B of Al-Jihad Kindergarten in Malang. Thus, both illustrated and writing flashcard can be used to stimulate the preschool's language development.
\end{abstract}

Keywords: preschool child, language development, flashcard

\section{ABSTRAK}

Periode prasekolah pada anak merupakan masa optimal dalam pertumbuhan dan perkembangan, seringkali disebut golden age.Perkembangan bahasa menjadi salah satu indikator dari kemampuan berbicara dan ketrampilan berbahasa anak. Pada usia prasekolah, sering juga terjadi masalah keterlambatan bahasa. Sehingga, diperlukan stimulasi bahasa yang tepat untuk meningkatkan perkembangan bahasa anak dengan menggunakan intervensi kartu edukasi bergambar dan kartu edukasi tulisan. Penelitian ini bertujuan untuk mengetahui perbedaan efektifitas antara stimulasi bahasa dengan metode Glenn Doman melalui kartu edukasi bergambar dan kartu edukasi tulisan terhadap perkembangan bahasa anak usia prasekolah di kelompok B TK Al-Jihad Kota Malang. Penelitian ini menggunakan rancangan penelitian Quasi Experimental dengan jenis pre test-post test one group design dan teknik purposive sampling dengan jumlah responden 32 anak yang diteliti pada bulan Februari-Maret 2019 menggunakan instrument penelitian DDST II (Denver Development Screening Test II) sebagai alat ukur 
perkembangan bahasa. Hasil uji Mann Whitney $\mathrm{p}$ value $0.551>0.05$, menunjukkan bahwa tidak terdapat perbedaan efektifitas stimulasi bahasa dengan metode Glenn Doman melalui kartu edukasi bergambar dan kartu edukasi tulisan terhadap perkembangan bahasa anak usia prasekolah di kelompok B TK Al-Jihad Kota Malang. Sehingga kartu edukasi bergambar maupun kartu edukasi tulisan memeiliki keefektifan yang dapat digunakan sebagai media stimulasi bahasa anak usia prasekolah.

Kata kunci: anak pra sekolah, perkembangan bahasa, kartu edukasi

*Korespondensi:Khansa Nisrina Firdaus. Surel: khansanfirdaus@gmail.com

\section{PENDAHULUAN}

Jumlah anak yang berusia 5-6 tahun di Jawa Timur diestimasikan sebanyak 9.603.173 anak, dengan perincian $4.911 .455(\ldots . . \%)$ berjenis kelamin laki-laki dan 4.691.718 berjenis kelamin perempuan. ${ }^{1}$ Periode prasekolah (36 bulan -72 bulan) merupakan masa optimal perkembangan dari seorang anak, seringkali juga disebut masa golden age.Seorang anak memiliki cirikhas yaitu tumbuh dan berkembang sejak masa konsepsi hingga masa remaja. Anak akanmenunjukkan ciriciri pertumbuhan dan perkembangan sesuai dengan usianya. ${ }^{2}$ Tumbuh kembang pada anak pra sekolah merupakan tahap dasar yang menjadi landasan yang dapat berpengaruh pada tahapan selanjutnya. Pada masa ini, anak mulai mengembangkan ketrampilan kesiapan bersekolah (mengikuti instruksi dan mengenal huruf), anak akan lebih mandiriserta akan lebih banyak menghabiskan waktu untuk bermain bersama dengan teman sebaya nya. ${ }^{3}$

\section{Dalam}

buku Asuhan Keperawatan Bayi dan Anak, Frankeburghmengungkapkan

bahwa perkembangan seorang anak, terbagi menjadi 4 aspek yaitu perkembangan motorik halus, motorik kasar, personal sosial dan bahasa. ${ }^{4}$ Sebuah studi Cochrane melaporkan bahwa anak prasekolah memiliki prevalensi keterlambatan bahasa sebesar 2,3-19\% hingga 40$60 \%$.Departemen Rehabilitasi Medik RSCM tahun 2006 mengatakan bahwa sebanyak 1125 pasien anakanak terdapat $10,13 \%$ mengalami keterlambatan bahasa Survey yang telah dilakukan pada anak prasekolah melaporkan bahwa 2,6\% anak usia 3-5 tahun mengalami keterlambatan bicara dan kesukaran dalam aspek kemampuan berbicara dan perkembangan bahasa. Menurut jurnal oleh Philip $R$ yang diterbitkan oleh Pediatrics menyebutkan bahwa 6-8\% anak TK mengalami masalah perkembangan bahasa.Sedangkan studi kasus di Utah pada International Classification of Diseases Classificationsdilaporkan bahwa terdapat 63.4 kasus setiap 1000 anak yang mengalami keterlambatan kemampuan bicara dan bahasa. ${ }^{5}$ Menurut dokter Amanda Soebandi, tahun 2013 mengatakan $5-8 \%$ anak mengalami keterlambatan bicara saat memasuki usia prasekolah. ${ }^{6}$

Roberta Minick (2016) mengatakan bahwa anak yang mengalami keterlambatan bicara dan bahasa memiliki kemungkinan besar mendapatkan masalah sosial, ekonomi, emosional saat ia dewasa.. Dampak yang dapat terjaditersebut tentunya menjadikan para orangtua semakin cemas. 
Menurut Depkes (2016), anak usia 4-6 tahun secara khusus dapat melakukan tugas perkembangan bahasa diantaranya senang bertanya tentang sesuatu, menjawab pertanyaan dengan kata yang benar dan bicaranya mudah dimengerti, menggunakan dan memahami 7 atau lebih kosakata. ${ }^{7}$ Sehingga ia mampumenjelaskanbentuk dan fungsi suatu benda. Saat usia 1,5 tahun paling tidak seorang anak telah dapat mengucapkan minimal 5 kosakata dengan konsisten. Terlebih lagi jika orangtua anak tersebut cenderung stres dan kurang tertarik dengan dunia pendidikan anak, orangtua akan menjadi jarang melakukan stimulasi seperti melatih belajar dan membaca kepada anak secara teratur. Menurut Michnick tahun 2015, kemampuan berbicara atau berbahasa anak juga ditentukan oleh riwayat berbahasa orangtuanya beserta stimulasi yang diberikan untuk membantu memperlancar perkembangan bahasa anak tersebut ${ }^{8}$

Menurut Santrock(2011) mengemukakan bahwa stimulasi yang memadahi akan memperoleh perkembangan yang optimal dalam segi bahasa. ${ }^{3}$ Hal ini juga sesuai dengan teori perkembangan bahasa menurut Piaget (2002), dalam tahapan pra-perasional mengikuti tahapan sensorimotor dan muncul antara 2 sampai 6 tahun. Gordon \& Browne menyatakan bahwa berbahasa bisa dikembangkan denganpermainan edukatif yang berfungsi untuk melatih komunikasi verbal dengan orang lain. Kartu edukasi diharapkan mampu meningkatkan kemapuan bahasa anak. Sebuah penelitian yang dilakukan pada anak Kelompok B di TK Pertiwi Kecamatan Bareng Kabupaten Jombang tahun 2015 menyimpulkan bahwa flashcard memiliki pengaruh yang signifikan pada perkembangan bahasa dan bicara anak. ${ }^{9}$ Bahkan, penelitian lain tahun 2015 yang dilakukan pada 21anak Kelompok B TK Negeri Pembina Kulonprogo Yogyakarta dengan desain penelitian Quasi Eksperimental dan metode prepost test design, yang diberikan permainan berupa kartu edukasi, didapatkan hasil bahwa media kartu edukasi tersebut berpengaruh pada perkembangan bahasa anak. ${ }^{10}$

Metode bermain anak merupakan salah satu alat ukur untuk menstimulasi pertumbuhan dan perkembangan anak. Contoh metode permainan yang dapat digunakan untuk memberi stimulus perkembangan bahasa anak adalah metode Glenn Doman melalui Kartu edukasi. Seorang ilmuwan bernama Glenn Doman. Pada tahun 1995 ia mendirikan The Institutes for The Achievement of Human dan mulai mengembangkan metode glenn doman. Metode ini merupakan cara belajar dengan menstimulasi perkembangan otak dengan menggunakan kartu edukasi atau flashcard.Teori glenn doman mengatakan bahwa memberikan pelajarananak membaca ialah dengan mengenalkan kata yang sering ia dengar dalam keseharian. Flashcard atau kartu edukasi merupakankartu bergambar yang disertai kata dan deskripsi bendanya. Cara memainkan kartu ini ialah dengan membacakan secara cepat untuk melatih konsentrasi anak sehingga dengan mengingat gambar yang ada maka 
perbendaharaan kata anak akan meningkat dan bertambah. ${ }^{11}$

Berdasarkan data balita dan anak prasekolah yang dideteksi tumbuh kembang nya di wilayah kerja Puskesmas Kendal Kerep Malang tahun 2018, menyebutkan bahwa kelurahan Bunulrejo memiliki penyimpangan SDIDTK (Stimulasi Dini dan Intervensi Dini Tumbuh Kembang Anak) tinggi dibanding kelurahan lainnya di Kota Malang (Dinkes Malang, 2018). Hal ini didukung dengan didapatannya data sebanyak $30 \%$ anak Kelompok B di TK Al Jihad Kelurahan Bunulrejo Kecamatan Blimbing Kota Malang yang mengalami keterlambatan bahasa dan bicara.TK Aljihad merupakan salah satu TK di Kota Malang yang memiliki jumlah murid cukup banyak.Murid pada kelompok B berjumlah 90 anak yang tesebar dalam 5 kelas.Setiap kelas berisi 25-30 anak dengan pengajar berjumlah satu orang. Berdasarkan studi pendahuluan yang telah dilakukan dari hasil data pemeriksaan menggunakan DDST/ Denver II dapat diintepretasikan bahwa 30\% anak kelompok B TK Aljihad mengalami suspect pada kolom bahasa.

\section{METODE PENELITIAN \\ Rancangan/Desain Penelitian}

Peneliti

menggunakan

rancangan studi quasy experimental melaluipre test-post test control group design, yaitu design yang menggunakan masing-masing kelompok diberikan perlakuan. Penelitian ini memiliki variabel dependen yaitu perkembangan bahasadan variabel independen intervensi kartu edukasi bergambar dan tulisan..

\section{Sumber Data}

Sumber data penelitian diperoleh melalui pemeriksaan DDST II (Denver Development Screening Test II), dan lembar checklist intervensi.

\section{Sasaran Penelitian}

Populasi dalam penelitian ini adalah seluruh anak prasekolah usia 5-6 tahun yang berada di TK Al Jihad Kota Malang. Teknik samplingmenggunakan Purposive sampling dengan sampel penelitian ialah anak yang memenuhi kriteria inklusi dan eksklusi sebanyak 32 responden.

\section{Pengembangan Instrumen dan Teknik Pengumpulan Data}

Instrumen penelitian yang digunakan dalam penelitian meliputi pemeriksaan DDST II (Denver Development Screening Test II), dan lembar checklist intervensi.

\section{Teknik Analisis Data}

Analisis data menggunakan uji wilcoxon untuk mengujikeefektifan masing-masing intervensi serta uji Mann whitney untuk membandingkan keefektifan kedua intervensi. Data diolah menggunakan SPSS for windows dengan nilai $\alpha \leq 0,05$

Penelitian ini sudah melalui prosesethicalclearance dan dinyata kanlaiketik oleh komisi etik penelitian kesehatan Fakultas Kedokteran Universitas Brawijaya Malang No. 45/EC/KEPK-S1KEB/02/2019. 
HASIL PENELITIAN

Analisis Univariat

Tabel 1. Distribusi Karakteristik Responden

\begin{tabular}{lcc}
\hline $\begin{array}{l}\text { Karakteristik } \\
\text { Responden }\end{array}$ & $\mathbf{N}$ & $\%$ \\
\hline $\begin{array}{l}\text { Jenis Kelamin } \\
\text { Laki-Laki }\end{array}$ & 17 & \\
$\quad$ Wanita & 15 & $53,12 \%$ \\
\hline $\begin{array}{l}\text { Usia (tahun) } \\
\quad 5 \text { tahun }\end{array}$ & 5 & $46,88 \%$ \\
$\quad 27$ & $15,7 \%$ \\
\hline tahun & & $84,3 \%$ \\
\hline $\begin{array}{l}\text { Pendidikan terakhir } \\
\text { orangtua }\end{array}$ & & \\
$\quad$ SD & 3 & $9,375 \%$ \\
SMP & 2 & $6,25 \%$ \\
$\quad$ SMA & 22 & $62,85 \%$ \\
$\quad$ Sarjana & 5 & $15,625 \%$ \\
\hline Pekerjaan orangtua & & \\
$\quad$ lbu rumah tangga & 16 & $50 \%$ \\
$\quad$ Wiraswasta & 10 & $31,25 \%$ \\
$\quad$ PNS & 6 & $18,75 \%$ \\
\hline
\end{tabular}

\section{Karakteristik Responden}

Pada tabel 1 menjelaskan tentang tentang karakteristik responden. Hasil yang diperoleh bahwa respondenberjenis kelamin laki-laki lebih banyak yaitu 17 anak $(53,12 \%)$, usia terbanyak adalah usia 6 tauhun sebanyak 27 anak (84,3\%), pendididkan terakhir orangtua terbanyak ialah lulusan SMA $(62,85 \%)$ serta pekerjaan orangtua paling banyak sebagai ibu rumah tangga (50\%).

\section{Karakteristik Responden Saat Pre test}

Setelah peneliti mendapatkan ijin dari pihak sekolah, peneliti melakukan pre test pemeriksaan tumbuh kembang menggunakan Denver II kepada anak terpilih sesuai dengan kriteria inklusi peneliti sejumlah 32 anak.
Responden tersebut tersebar dari kelas $B 1$ hingga $B$ yang terdiri dari 9 anak dari B1, 7 anak dari B2, 6 anak dari B3, 2 anak B4, dan 8 anak dari B5. Anak berjenis kelamin laki-laki sejumlah 17 anak dan anak perempuan sejumlah 15 anak.Anak berusia 5 tahun berjumlah 5 anak dan anak berusia 6 tahun berjumlah 27 anak.

Berdasarkan data yang diperoleh dari buku absensi masingmasing walikelas bahwa sebagian besar pendidikan terakhir orangtua responden ialah lulusan SMA dan pekerjaan orangtua terbanyak ialah sebagai ibu rumah tangga. Peneliti juga mendapatkan informasi dari masing-masing walikelas bahwa semua responden jarang diberikan stimulasi bahasa di rumah oleh orangtuanya dikarenakan berbagai 
macam alasan diantaranya orangtua teralu sibuk bekerja, fokus orangtua terbagi kepada saudara kandung responden, keterbatasan pendidikan dan pengetahuan orangtua serta minimnya intensitas komunikasi secara langsung antara anak dengan orangtua saat berada di rumah.

Selain itu, pihak sekolah juga mengatakan bahwa tidak memiliki fasilitas media khusus pembelajaran untuk menunjang stimulasi bahasa anak seperti kartu edukasi. Sehingga hal ini sejalan dengan hasil pretest yang didapatkan peneliti bahwa sebanyak 32 responden mengalami suspect pada kolom bahasa pada tes Denver II.

\section{Karakteristik Responden Saat Pre test}

Peneliti

melakukan pengelompokan responden kedalam dua kelompok yaitu kelompok intervensi kartu edukasi bergambar dan kelompok intervensi kartu edukasi tulisan. Setiap kelompok berisi 16 anak yang akan dipandu dan dibimbing langsung oleh satu guru untuk diberikan intervensi kartu edukasi.

Pada kelompok kartu edukasi bergambar berdasarkan jenis kelamin terdapat 8 anak perempuan dan 8 anak perempuan.Dari segi usia, anak usia 5 tahun sebanyak 3 angka serta usia 6 tahun sejumlah 13 anak. Sebagian besar ialah ibu rumah tangga serta pendidikan terakhir ialah Iulusan Sekolah Menengah Atas.

Sedangkan pada kelompok kartu edukasi tulisan berdasarkan jenis kelamin terdapat 7 anak perempuan dan 9 anak perempuan. Berdasarkan usia, anak yang berusia 5 tahun sebanyak 2 angka dan berusia 6 tahun sebanyak 14 anak. Sama halnya dengan kelompok kartu edukasi bergambar, sebagian besar pekerjaan dari orangtua sebagai ibu rumah tangga dan pendidikan terakhir paling banyak yaitu lulusan SMA.

Setelah diberikan intervensi kartu edukasi secara rutin selama 2 minggu pada masing-masing kelompok, peneliti melakukan post test untuk menilai perkembangan bahasa anak.Perhitungan usia kronologis anak dilakukan mendekati waktu pelaksanaan pemberian intervensi dengan kartu edukasi bergambar maupun kartu edukasi tulisan. Post test dilakukan dengan menggunakan tes Denver II seperti halnya pada saat pre test. Hasil yang didapatkan pada post test yaitu masih sebanyak 4 anak dengan intrepetasi suspect pada kolom saat diberikan tes Denver II. Rincian anak dengan hasil suspect tersebut ialah 1 anak dari kelompok intervensi kartu edukasi bergambar dan 3 anak dari kelompok kartu edukasi tulisan. Hal ini membuktikan bahwa terdapat peningkatan pekembangan bahasa anak saat sebelum dan sesudahpada kelompok kartu bergambar dan tulisan yang sudah dilakukan selama 2 minggu.

\section{Analisis Bivariat}

Berdasar kan tabel uji statis tik Wilcoxonmenunjukkan hasil perubahan yang sangat signifikan bernilai 0,000 antara hasil pretest dan post test $(P$ Value $>0.05$ ) bahwa intervensi kartu edukasi bergambar dan kartu edukasi tulisan sangat bermakna memberikan perubahanperkembangan bahasa pada anak kelompok $B$. 


\section{Tabel 2: Perbedaan Perkembangan keefektifan intervensi kartu edukasi bergambar dan kartue dukasi tulisan}

\begin{tabular}{|c|c|c|c|c|}
\hline \multirow[b]{2}{*}{ Jenis intervensi } & \multicolumn{2}{|c|}{ Hasil post test } & \multirow[b]{2}{*}{ Total } & \multirow{2}{*}{$\begin{array}{c}P \text { value } \\
\text { (nilai } \\
\text { signifikasi) }\end{array}$} \\
\hline & Normal & Suspect & & \\
\hline $\begin{array}{l}\text { Kartu edukasi } \\
\text { bergambar }\end{array}$ & 15 & 1 & 16 & \multirow{2}{*}{0,551} \\
\hline $\begin{array}{l}\text { Kartu edukasi } \\
\text { tulisan }\end{array}$ & 13 & 3 & 16 & \\
\hline
\end{tabular}

Berdasarkan data diatas dari uji SPSS untuk perbandingan kedua intervensi menunjukkan hasil dari nilai $P$ value sebesar $0,551>0,05$, maka dapat disimpulkan bahwa $\mathrm{H}_{0}$ diterima sehingga menunjukkan bahwa tidak terdapat perbedaan yang signifikan antara intervensi kartu edukasi bergambar dan kartu edukasi tulisan terhadap perkembangan bahasa anak. Sehingga kedua intervensi tersebut dapat dijadikan media untuk peningkatan kemampuan bahasa anak usia prasekolah.

\section{PEMBAHASAN}

Berdasarkan hasil penelitian dari 32 responden ini menunjukkan bahwa persentase responden lakilaki $(53,12 \%)$ lebih banyak dibandingkan dengan reponden perempuan $(46,88 \%)$. Jenis kelamin memiliki pengaruh penting dalam perkembangan bahasa anak. Ragam kosakata anak perempuan lebih banyak dibandingkan anak laki-laki yang menujukkan bahwa perkembangan bahasa anak perempuan lebih unggul. Santrock mengungkapkan bahwa area verbal seperti menemukan sinonim dan mememori verbal anak perempuan lebih baik. Sedangkan laki-laki lebih unggul dalam kemampuankuantitatif dan visual spasial. ${ }^{3} \mathrm{Hal}$ ini sejalan dengan penelitian Sidiarto (2002) yang menunjukan jenis kelamin anak dengan keterlambatan bahasa lebih banyak laki laki dibandingkan perempuan, hal ini didukung oleh pernyataan Sidiarto bahwa perbandingan nya bisa mencapai $8: 1^{12}$

Selain jenis kelamin, berdasarkan hasil penelitian ini menunjukkan bahwa dari 32 responden yang diteliti, persentase responden yang berusia 6 tahun $(84,3 \%)$ lebih banyak dibandingkan dengan reponden yang berusia 5 tahun (15,7\%). Menurut Seefeldt \& Wasik, pada usia lima tahun perbendaharaan kata-kata anak meluas mencapai 5.000 ke 8.000 kata. ${ }^{13}$ Dalam penelitian Dhieni mengatakan bahwa menjelang usia 5-6 tahun, anak dapat memahami sekitar 8.000 kata $^{14}$

Dilihat dari data karakteristik responden berdasarkan pekerjaan orangtua sebanyak $56,25 \%$ (9 orang) pada kelompok kartu edukasi bergambar dan $43,75 \%$ (7 orang) pada kelompok kartu edukasi tulisan merupakan ibu rumah tangga. Sedangkan data berdasarkan tingkat pendidikan terakhir orangtua sebanyak $75 \%$ (12 orang) pada kelompok kartu edukasi bergambar dan $62.5 \%$ (10 orang) pada kelompok kartu edukasi tulisan merupakan lulusan SMA memiliki 
jumlah terbanyak pada masingmasing kelompok. Papalia, Olds \& Feldeman mengungkapkanbahwa tingkat pendidikan ibu dapat memiliki pengaruh pada keterlambatan bahasa anak. Orangtua seharusnya memberikan stimulasi dan pembelajaran sehingga mampu meningkatkan kemapuan bahasa anak. Soetjiningsih \& Ranuh (2007)mengungkapkan bahwa pendidikan orang tua ada kaitannya dengan pola asuh dan perkembangan anak. Selain itu, anak yang berasal dari keluarga ekonomi kurang mampu dari segi sosial ekonomimemungkinkan mengalami keterlambatan bahasan.Hal ini dapat disebabkan minimnya kurangnya kesempatan belajar pada anak dari keluarga kurang mampu.Kematangan finansial keluarga yang memadai dapat menunjang tumbuh kembang anak dari mulai kebutuhan primer maupun sekunder. ${ }^{15}$

Secara teoritis, hal lain diduga dapat mempengaruhi perkembangan bahasa anak ialah terakit hubungan dengan keluarga dan lingkungannya. Lingkungan kampung dengan kondisi kekeluargaan dan sosialisasi masih baik, sehingga kontak anak dengan teman sebaya masih cukup efektif untuk mendorong perkembangan bahasa anak. ${ }^{16}$

Berdasarkan analisis statistic pada studi kami menyimpulkan dari kedua intervensi tersebut menghasilkan perubahan yang sangat signifikan antara hasil pretest dan post test $(P$ Value $>0.05$ ) dengan rincian hasil pada intervensi kelompok intervensi kartu edukasi bergmabra dan kartu edukasi tulisan yang masing-masing bernilai $p=0.000$. Peningkatan kemampuan bahasa terjadi karena adanya penerapan metode bantuan flashcard/ kartu edukasi yang menarik karena ada gambar, ukuran dan permainan warna.

\section{SIMPULAN}

Tidak terdapat perbedaan efektifitasantara Stimulasi Bahasa dengan Metode Glenn Doman melalui Kartu edukasi Bergambar dan Kartu edukasi Tulisan terhadap Perkembangan Bahasa dengan nilai signifikan 0,551>0,05.

\section{DAFTAR PUSTAKA}

1. Kementerian Kesehatan RI. (2012). Profil Kesehatan Indonesia. Jakarta

2. Depkes RI. (2010). Profil Kesehatan Indonesia Tahun 2009. Jakarta: Depkes RI

3. Santrock, John W. (2011). Masa Perkembangan Anak Jilid 1. Jakarta : Salemba Medika

4. Susilaningrum, Rekawati dkk. (2013). Asuhan Keperawatan Bayi dan anak : untukPerawat dan Bidan Edisi 2. Jakarta : Salemba Medika

5. Simeonsson, R. J., Scarborough, A. A., \& Hebbeler, K. M. (2006). ICF and ICD codes provide a standard language of disability in young children. Journal of Clinical Epidemiology, 59(4), 365-373.

6. DepKes, R. I. (2006). Profil Kesehatan Indonesia Tahun 2004. Kesehatan, K.(Ed.).

7. Golinkoff, R. M., Can, D. D., Soderstrom, M., \& Hirsh-Pasek, K. (2015). (Baby) talk to me: The social context of infant-directed speech and its effects on early language acquisition. Current Directions in Psychological Science, 24(5), 339344. 
8. R, Moeslichatoen. (1999). Metode Pengajaran di Tamam KanakKanak. Jakarta. Rineka Cipta

9. Teresa, M. A., \& Simatupang, N. D. (2015). Pengaruh Media Kartu Bergambar Terhadap Kemampuan Berbicara Anak Kelompok B. Paud Teratai, 4(3).

10. Ayib, N. M., \& Khusnal, E. (2015). Pengaruh Bermain Edukatif dengan Media Flashcard terhadap Perkembangan Bahasa Anak Usia 5-6 Tahun di TK Negeri Pembina Wates Kulonprogo(Doctoral dissertation, STIKES'Aisyiyah Yogyakarta).

11. Ahmad Susanto. (2011).

Perkembangan Anak Usia Dini. Jakarta: Kencana. Prenada

12. Sidiarto L. (2002). Gangguan perkembangan bahasa dan bicara pada keterlambatan bahasa. dalam simposium neuropediatri " child who does not speak ". Semarang : Badan Penerbit Universitas Diponegoro;3.

13. Hartati, S., \& Fitria, E. (2018). Peningkatan Kemampuan Berbicara Anak Usia 5-6 Tahun Melalui Dongeng di Kelompok Bermain AzZakiyyah. Ceria: Jurnal Pendidikan Anak Usia Dini, 5(2), 1-12.

14. Dhieni, N., Fridani, L., Muis, A., \& Yarmi, G. (2014). Metode pengembangan bahasa. Jakarta : Universitas Terbuka

15. Soetjiningsih. Perkembangan anak dan permasalahannya. Dalam: Narendra MB, Sularyo $S$, Soetjiningsih, Suyitno H, Ranuh IG, penyunting. (2002).Buku Ajar Tumbuh Kembang Anak dan Remaja; Edisi I. Jakarta: Ikatan Dokter Anak Indonesia. Jakarta: Sagung Seto

16. Soetjiningsih. Perkembangan (2012). Permasalahannya dalam Buku Ajar I
IImu Perkembangan Anak Dan Remaja. Jakarta : Sagungset 